\title{
Effects of gender of dairy or beef cattle and the number of pair of permanent incisors on carcass traits
}

\author{
Kunya Tuntivisoottikul ${ }^{1 *}$ and Rutcharin Limsupavanich ${ }^{2}$ \\ ${ }^{1}$ Department of Agricultural Education, Faculty of Industrial Education and Technology, King Mongkut's Institute of Technology \\ Ladkrabang, Bangkok, Thailand \\ ${ }^{2}$ Department of Animal Production Technology and Fisheries, Faculty of Agricultural Technology, King Mongkut's Institute of \\ Technology Ladkrabang, Bangkok, Thailand
}

\begin{abstract}
Effects of group of cattle (gender of dairy or beef cattle) and number of pair of permanent incisors (0-4 pairs) on carcass traits were investigated. Data collected from 2,059 carcasses were obtained from beef cattle cooperative in 2016. Carcass traits included slaughter weight (wt.), hot carcass wt., percentage of hot or chilled carcass wt., chilling loss, skin wt., and marbling score. Factors included group of cattle and number of pair of permanent incisors observed in each cattle group, while slaughter wt. was a co-variable in the statistical model. Descriptive statistics were used to analyze marbling score. Results showed that group of cattle affected slaughter wt., hot carcass wt., percentage of hot or chilled carcass wt., skin wt. $(\mathrm{P}<0.0001)$, and chilling loss $(\mathrm{P}<0.05)$. Number of pair of permanent incisors within each cattle group affected all carcass traits $(p<0.05)$, except chilling loss $(p>0.05)$. Female and male beef cattle in all ages had higher hot carcass wt. and percentage of hot or chilled carcass wt. than female and male dairy cattle. The highest marbling score of 5 was found in female and male beef and female dairy cattle with 4 pairs of permanent incisors. However, majority of cattle had marbling score 2.
\end{abstract}

\section{Introduction}

In 2006, the beef cattle population in Thailand was approximately 8.04 million heads, but it decreased to 4.41 million heads in 2015, of which $3.90 \%$ were finishing beef cattle [1]. Most of the finishing beef cattle are crosses of Bos indicus (Native or Brahman or their crosses) and Bos taurus (Charolais, Simental, Limousin, etc.). Currently, beef production is not enough for local consumption. An alternative was done by insemination of dairy cows to produce crossbreds for meat production. In addition, culled dairy cows or male dairy cattle are raised as beef cattle [2]. Most dairy cattle are at least $75 \%$ Holstein Friesian (HF) blood. Only females are needed for milk production. Culled dairy cattle, especially male, are sold at a cheaper price. Some dairy farmers, therefore, continue raising them for meat production. At present, about $20 \%$ of dairy meat is shared in beef market. Important intrinsic factors influencing carcass traits are breed, gender, and age or maturity of the animals. Carcass wt. and gender of cattle are common criteria for carcass classification [3]. Dentition is generally used to evaluate cattle age, as actual birthdates are not usually available [3-4]. South African carcass classification scheme and the Australian Meat system use dentition to estimate physiological age or maturity of cattle for beef carcass classification [3].
Dentition classification and its criteria for classification can be different among countries. In Thailand, the dentition at slaughter is recorded in number of pair of incisors $\left(0,1,2,3\right.$, and 4 mean none, the $1^{\text {st }}, 2^{\text {nd }}, 3^{\text {rd }}$, and $4^{\text {th }}$ pairs of permanent incisors were observed). For commercial beef production, physiological age is as important factor influencing carcass traits as slaughter wt. In general, cattle with 0 , the $1^{\text {st }}, 2^{\text {nd }}, 3^{\text {rd }}$, and $4^{\text {th }}$ permanent incisors are $<18,18-24,24-30,36$, and $42-$ 48 months of age, respectively. Reports comparing carcass traits based on gender of dairy or beef cattle and their physiological ages, especially under commercial production in Thailand, are a few [5-7], comparing to those in other countries [8-12]. Therefore, we investigated carcass traits as affected by gender of dairy or beef cattle and their physiological age, according to the number of pair of permanent incisors.

\section{Material and methods}

\subsection{Data collection}

Data were collected from 2,059 cattle obtained from the Beef Cluster Cooperative Limited located in Nakhon Pathom Province during 2016. Information on animal identification and farm origin was recorded. Cattle were

Corresponding author: kunya.tu@kmitl.ac.th 
separated into 4 groups including 398 female and 173 male dairy cattle and 354 female and 1,134 male beef cattle (FD, MD, FB, and MB, respectively). The beef cattle are minimum $50 \%$ Charolais and $50 \%$ Brahman or Native or their crosses, while the dairy cattle are at least $75 \%$ HF. Cattle were raised intensively by feeding with fresh grasses and concentrate until body wt. reached 500 to $550 \mathrm{~kg}$. The cattle were then transported to a slaughterhouse. They were rested for $12 \mathrm{hrs}$ prior to slaughtering. After bleeding, images of their teeth were taken using a digital camera. The number of pair of permanent incisors was observed from the image. The skin was removed and weighed. After evisceration, carcass splitting, and slaughtering process, hot carcass wt. was obtained from both sides of each carcass. After 7 days of aging $\left(4^{\circ} \mathrm{C}\right)$, chilled carcass wts. were obtained. Carcass was then quartered between the $12^{\text {th }}$ to $13^{\text {th }}$ ribs. Intramuscular fat (marbling) on the surface of $M$. longissimus dorsi on the $12^{\text {th }}$ ribs of the right carcass side was evaluated (score 1 to 5 , where $1=$ devoid, 2 = slight, 3 = small, $4=$ moderate, and $5=$ abundant) [13]. Percentage of hot or chilled carcass wt. was calculated.

\subsection{Data analysis}

Effects of cattle group and the numbers of pair of permanent incisors on carcass traits were analyzed using two general linear models. The difference in slaughter wts. was tested by model (1), while other carcass traits, except marbling score, were analyzed using model (2). Slaughter wt. was used as covariate in model (2). Since the categories of independent variable, the number of pair of permanent incisors of animal within each cattle group, were unequal, nested model was performed as follows:

$$
\begin{aligned}
& y_{i j k}=\mu+G C_{i}+\operatorname{Pt}(G C)_{i j}+\varepsilon_{i j k} \\
& y_{i j k}=\mu+G C_{i}+\operatorname{Pt}(G C)_{i j}+\beta\left(S W_{i j k}-\overline{S W}\right)+\varepsilon_{i j k}
\end{aligned}
$$

Where: $y_{i j}=$ Observation of slaughter wt. of animal k in each gender $i ; y_{i j k}=$ Observation of the studied traits of animal $\mathrm{k}$ in each gender $\mathrm{i} ; \mu=$ Overall mean; $G C_{i}=$ Group of gender as fixed effect $(\mathrm{i}=1,2,3$ and 4 , where $1=$ female beef cattle, $2=$ female dairy cattle, $3=$ male beef cattle, and $4=$ male dairy cattle); $\operatorname{Pt}(G C)_{i j}=$ Pairs of permanent incisors of animal within each gender of beef or dairy cattle as co-factors $(\mathrm{j}=0,1,2,3$, and 4 , where 0 $=$ none, $1,2,3$, and $4=1^{\text {st }}, 2^{\text {nd }}, 3^{\text {rd }}$, and $4^{\text {th }}$ pair of permanent incisors observed); $\beta=$ Coefficient regression of the studied traits to the slaughter wt.; $S W_{i j k}=$ Slaughter wt. of the animal $\mathrm{k}$ in each gender group $\mathrm{i}$ and in each group of observed pairs of permanent incisors $\mathrm{j} ; \overline{S W}=$ Mean of slaughter wt.; $\varepsilon_{i j k}=$ Error of experiment of the observation $y_{i j k}$

Differences among means were compared with pdiff option in GLM procedure using statistical software [14].
Descriptive statistic in term of measured frequency was used for marbling score data analysis.

The distribution of all carcass trait data was as fallows. Average slaughter wt., hot carcass wt., chilling loss and skin wt. were 589.48, 342.30, 7.73, and 44.75 $\mathrm{kg}$, respectively. Dressing percentage, both hot carcass and chilled carcass wts, were 58.03 and $56.71 \%$, respectively. Animals in this population obtained marbling in mode with 2 .

\section{Results and discussions}

\subsection{Factors affecting carcass traits}

The effects of group of cattle and the number of pair of permanent incisors of animals within group of cattle on carcass traits are shown in Table 1. Group of cattle and the number of pair of permanent incisors significantly influenced slaughter wt. $(\mathrm{P}<0.0001)$, but with low $\mathrm{R}^{2}$ values (0.06). Because there were many factors which could affect slaughter wt., for example, feeding, animal handling at the farms or during transportation to the slaughterhouse. All carcass traits were affected by group of cattle and by number of pair of permanent incisors $(\mathrm{P}<0.05)$. But chilling loss was affected only by group of cattle $(\mathrm{P}<0.05)$. Our results agreed with previous study [5], who reported that group of cattle, including beef steers, dairy steers, and culled dairy cows, and the number of pair of permanent incisors had an influence on cold carcass wt., dressing percentage, and skin wt. $(\mathrm{P}<0.05)$.

Table 1. Effects of slaughter weight, group of cattle, and number of pair of permanent incisors within group of cattle on carcass traits

\begin{tabular}{lcccc}
\hline & & \multicolumn{3}{c}{$\begin{array}{c}\text { No.pair of } \\
\text { permanent } \\
\text { incisors }\end{array}$} \\
$\begin{array}{l}\text { Carcass traits/ } \\
\text { Factor }\end{array}$ & $\begin{array}{c}\text { Slaughter } \\
\text { weight }\end{array}$ & $\begin{array}{c}\text { Group } \\
\text { of cattle } \\
\text { (GC) }\end{array}$ & $\begin{array}{c}\text { within GC } \\
(\mathrm{Pt}(\mathrm{GC}))\end{array}$ & $\mathrm{R}^{2}$ \\
\hline $\begin{array}{l}\text { Slaughter } \\
\text { weight, kg }\end{array}$ & - & $<0.0001$ & $<0.0001$ & 0.06 \\
$\begin{array}{l}\text { Hot carcass } \\
\text { weight, kg }\end{array}$ & $<0.0001$ & $<0.0001$ & $<0.0001$ & 0.91 \\
$\begin{array}{l}\text { Hot carcass } \\
\text { weight, \% }\end{array}$ & $<0.0001$ & $<0.0001$ & 0.0001 & 0.42 \\
$\begin{array}{l}\text { Chilled carcass } \\
\text { weight, \% }\end{array}$ & $<0.0001$ & $<0.0001$ & 0.0001 & 0.43 \\
$\begin{array}{l}\text { Chilling loss,kg } \\
\text { Skin weight,kg }\end{array}$ & $<0.0001$ & 0.0156 & 0.1930 & 0.25 \\
\hline & $<0.0001$ & $<0.0001$ & $<0.0001$ & 0.56 \\
\hline
\end{tabular}

\subsection{The effect of gender of dairy or beef cattle (group of cattle)}

Least squares means and standard errors of carcass traits as affected by group of cattle were as follows: FB had the lowest slaughter wt. $(546.42 \pm 11.04 \mathrm{~kg})$. MB showed the highest slaughter wt. $(603.70 \pm 3.74 \mathrm{~kg})$, but it did not differ $(\mathrm{P}>0.05)$ from MD $(589.79 \pm 10.26 \mathrm{~kg})$. FB and 
MB had higher $(\mathrm{P}<0.05)$ hot carcass wts., and percentages of hot and chilled carcass wts. than FD and MD. Previous study reported that carcass wt. obtained from live wt. or dressing percentage for HF steers was typically less than that of beef steers [15]. The reduced yields were affected by increased proportion of gut [1617], reduced subcutaneous fat [18], increased liver size, and increased proportion of abdominal fats as mesenteric and omental fat [17]. It is interested that although FB had the lowest slaughter wt., they had higher hot carcass wt. and percentages of hot and chilled carcass wts. than FD and MD. The hot carcass wt. and percentages of hot and chilled carcass wts. of FD in the present study were similar to those from dairy cows with slaughter wt. of 550 to $649 \mathrm{~kg}$, previously studied in Thailand [19], which had hot carcass wt. of $318.05 \pm 1.84 \mathrm{~kg}$, percentage of hot carcass wt. of $53.87 \pm 0.23$, and percentage of chilled carcass wt. of $52.51 \pm 0.24$, respectively.

FB and MB carcasses had lower chilling loss than MD carcasses $(\mathrm{P}<0.05)$, but did not differ from FD carcasses. Skin wt. of MB was the greatest $(48.11 \pm 0.32$ $\mathrm{kg}$ ), while that of FD was the least $(38.89 \pm 0.60 \mathrm{~kg})$. There was no difference $(\mathrm{P}>0.05)$ in skin wt. of $\mathrm{FB}$ and MD (44.66 \pm 0.94 and $42.87 \pm 0.87 \mathrm{~kg}$, respectively). Previous studies reported skin wts. of $35.95 \pm 0.53 \mathrm{~kg}$ for culled dairy cows with slaughter wt. of 550 to $649 \mathrm{~kg}$ and $43.50 \pm 2.55 \mathrm{~kg}$ for dairy steers with 550 to $599 \mathrm{~kg}$ slaughter wt. [20-21].

For percentage distribution of animals in each group of cattle graded into each marbling score, results showed that total percentages of cattle in score 1 to 5 were 39.58 , $40.26,15.06,3.98$, and $1.12 \%$, respectively. All groups of cattle were graded into score 1 to 5 , except for MD which had score 1 to 4 . The majority of cattle (40.26\%) had marbling score 2. Interestingly, $9.28 \%$ of FD had score 2 and $6.36 \%$ was graded score 1 . For female, 6.95 $\%$ FB had score 1, which was similar to FD (6.36\%). However, the percentage of FD graded score 2 was more than that of FB (9.28 and $6.70 \%$, respectively). For male cattle, the percentages of $\mathrm{MB}$ and MD with marbling score 1 were 21.81 and $4.47 \%$, respectively, which was slightly more than those with score 2 (21.03 and $3.25 \%$ for $\mathrm{MB}$ and $\mathrm{MD}$, respectively).

\subsection{Effects of number of pair of permanent incisors on carcass traits}

Pairs of permanent incisors of animal within gender of cattle breeds affected the carcass traits (Table 2). No FD with zero pair of permanent incisors was found. Because culled dairy cows were generally older than one year. MD and FD with the $4^{\text {th }}$ pair of incisors had the least hot carcass wts., but were not different from those of FD with the $1^{\text {st }}$ and $3^{\text {rd }}$ pairs of incisors. Similar results were also found in percentages of hot and chilled carcass wts. $\mathrm{FB}$ and $\mathrm{MB}$ in all maturity categories, except the most mature groups ( $4^{\text {th }}$ pair of incisors), had more hot carcass wt. and dressing percentages than FD and MD at all ages. Interestingly, carcass trait values of the most mature group ( $4^{\text {th }}$ pairs of permanent incisors) were lower than those of the younger $\left(1^{\text {st }}, 2^{\text {nd }}\right.$, and $3^{\text {rd }}$ pairs $)$.
Table 2. Least squares means and standard errors (LSM \pm SE) of studied traits affected by number of pair of permanent incisors of each cattle group.

\begin{tabular}{|c|c|c|c|c|c|c|}
\hline $\mathrm{Pt}$ & GC & $\mathrm{n}$ & $\begin{array}{c}\mathrm{HCW} \\
\mathrm{LSM} \\
\pm \mathrm{SE} \\
\end{array}$ & $\begin{array}{c}\text { PHCW } \\
\text { LSM } \\
\pm \text { SE } \\
\end{array}$ & $\begin{array}{c}\mathrm{PCCW} \\
\mathrm{LSM} \\
\pm \mathrm{SE} \\
\end{array}$ & $\begin{array}{c}\text { SKW } \\
\text { LSM } \\
\pm \text { SE } \\
\end{array}$ \\
\hline 0 & FB & 2 & $\begin{array}{l}354.95 \\
\pm 10.63^{\mathrm{f}}\end{array}$ & $\begin{array}{l}60.59 \\
\pm 1.79^{\mathrm{f}}\end{array}$ & $\begin{array}{c}59.13 \\
\pm 1.79^{\mathrm{f}}\end{array}$ & $\begin{array}{l}50.08 \\
\pm 4.44^{\mathrm{de}}\end{array}$ \\
\hline 1 & FB & 30 & $\begin{array}{l}347.74 \\
\pm 2.75^{\text {def }}\end{array}$ & $\begin{array}{l}58.96 \\
\pm 0.46^{\mathrm{def}}\end{array}$ & $\begin{array}{c}57.68 \\
\pm 0.46^{\text {def }}\end{array}$ & $\begin{array}{l}45.80 \\
\pm 1.15^{\mathrm{cd}}\end{array}$ \\
\hline 2 & FB & 85 & $\begin{array}{l}349.89 \\
\pm 1.63^{\text {ef }}\end{array}$ & $\begin{array}{l}59.39 \\
\pm 0.27^{\text {ef }}\end{array}$ & $\begin{array}{l}58.12 \\
\pm 0.27^{\mathrm{f}}\end{array}$ & $\begin{array}{l}44.52 \\
\pm 0.68^{\mathrm{bc}}\end{array}$ \\
\hline 3 & FB & 104 & $\begin{array}{l}347.84 \\
\pm 1.48^{\text {ef }}\end{array}$ & $\begin{array}{l}59.03 \\
\pm 0.25^{\text {def }}\end{array}$ & $\begin{array}{c}57.79 \\
\pm 0.25^{\mathrm{ef}}\end{array}$ & $\begin{array}{l}42.61 \\
\pm 0.62^{\mathrm{b}}\end{array}$ \\
\hline 4 & FB & 133 & $\begin{array}{l}342.86 \\
\pm 1.31^{\mathrm{d}}\end{array}$ & $\begin{array}{l}58.17 \\
\pm 0.22^{\mathrm{d}}\end{array}$ & $\begin{array}{c}56.86 \\
\pm 0.22^{\mathrm{d}}\end{array}$ & $\begin{array}{l}40.27 \\
\pm 0.55^{\mathrm{b}}\end{array}$ \\
\hline 1 & FD & 9 & $\begin{array}{l}324.28 \\
\pm 5.01^{\mathrm{abc}}\end{array}$ & $\begin{array}{l}54.84 \\
\pm 0.84^{\mathrm{abc}}\end{array}$ & $\begin{array}{c}53.44 \\
\pm 0.84^{\text {abc }}\end{array}$ & $\begin{array}{l}41.84 \\
\pm 2.09^{\mathrm{b}}\end{array}$ \\
\hline 2 & FD & 46 & $\begin{array}{l}325.31 \\
\pm 2.22^{\mathrm{bc}}\end{array}$ & $\begin{array}{l}55.04 \\
\pm 0.37^{\text {abc }}\end{array}$ & $\begin{array}{c}53.64 \\
\pm 0.37^{\mathrm{abc}}\end{array}$ & $\begin{array}{l}38.46 \\
\pm 0.92^{\mathrm{a}}\end{array}$ \\
\hline 3 & FD & 96 & $\begin{array}{l}321.54 \\
\pm 1.53^{\mathrm{ab}}\end{array}$ & $\begin{array}{l}54.56 \\
\pm 0.26^{\mathrm{ab}}\end{array}$ & $\begin{array}{c}53.21 \\
\pm 0.26^{\text {ab }}\end{array}$ & $\begin{array}{l}38.26 \\
\pm 0.64^{\mathrm{a}}\end{array}$ \\
\hline 4 & FD & 247 & $\begin{array}{l}317.55 \\
\pm 0.96^{\mathrm{a}}\end{array}$ & $\begin{array}{l}53.85 \\
\pm 0.16^{\mathrm{a}}\end{array}$ & $\begin{array}{c}52.52 \\
\pm 0.16^{\mathrm{a}}\end{array}$ & $\begin{array}{l}37.01 \\
\pm 0.39^{\mathrm{a}}\end{array}$ \\
\hline 0 & $\begin{array}{l}\mathrm{M} \\
\mathrm{B}\end{array}$ & 29 & $\begin{array}{l}351.68 \\
\pm 2.79^{\text {ef }}\end{array}$ & $\begin{array}{l}59.57 \\
\pm 0.47^{\mathrm{f}}\end{array}$ & $\begin{array}{c}58.26 \\
\pm 0.47^{\mathrm{f}}\end{array}$ & $\begin{array}{l}52.22 \\
\pm 1.16^{\mathrm{e}}\end{array}$ \\
\hline 1 & $\begin{array}{l}\mathrm{M} \\
\mathrm{B}\end{array}$ & 380 & $\begin{array}{l}350.52 \\
\pm 0.77^{\text {ef }}\end{array}$ & $\begin{array}{l}59.43 \\
\pm 0.13^{\text {f }}\end{array}$ & $\begin{array}{c}58.12 \\
\pm 0.13^{\mathrm{f}}\end{array}$ & $\begin{array}{l}48.87 \\
\pm 0.32^{\mathrm{d}}\end{array}$ \\
\hline 2 & $\begin{array}{l}\mathrm{M} \\
\mathrm{B}\end{array}$ & 517 & $\begin{array}{l}351.79 \\
\pm 0.66^{\mathrm{f}}\end{array}$ & $\begin{array}{l}59.61 \\
\pm 0.11^{\mathrm{f}}\end{array}$ & $\begin{array}{c}58.31 \\
\pm 0.11^{\mathrm{f}}\end{array}$ & $\begin{array}{l}48.15 \\
\pm 0.28^{\mathrm{d}}\end{array}$ \\
\hline 3 & $\begin{array}{l}\mathrm{M} \\
\mathrm{B}\end{array}$ & 155 & $\begin{array}{l}349.74 \\
\pm 1.22^{\text {ef }}\end{array}$ & $\begin{array}{l}59.21 \\
\pm 0.20^{\text {ef }}\end{array}$ & $\begin{array}{c}57.91 \\
\pm 0.20^{\text {ef }}\end{array}$ & $\begin{array}{l}47.35 \\
\pm 0.51^{\mathrm{d}}\end{array}$ \\
\hline 4 & $\begin{array}{l}\mathrm{M} \\
\mathrm{B}\end{array}$ & 53 & $\begin{array}{l}346.55 \\
\pm 2.07^{\text {de }}\end{array}$ & $\begin{array}{l}58.70 \\
\pm 0.35^{\mathrm{de}}\end{array}$ & $\begin{array}{c}57.35 \\
\pm 0.35^{\mathrm{de}}\end{array}$ & $\begin{array}{l}43.97 \\
\pm 0.86^{\mathrm{bc}}\end{array}$ \\
\hline 0 & $\begin{array}{l}\mathrm{M} \\
\mathrm{D}\end{array}$ & 6 & $\begin{array}{l}330.13 \\
\pm 6.14^{\mathrm{c}}\end{array}$ & $\begin{array}{l}55.68 \\
\pm 1.03^{\mathrm{bc}}\end{array}$ & $\begin{array}{c}54.41 \\
\pm 1.03^{\mathrm{bc}}\end{array}$ & $\begin{array}{l}45.09 \\
\pm 2.56^{\text {bcd }}\end{array}$ \\
\hline 1 & $\begin{array}{l}\mathrm{M} \\
\mathrm{D}\end{array}$ & 76 & $\begin{array}{l}329.66 \\
\pm 1.72^{\mathrm{c}}\end{array}$ & $\begin{array}{l}55.91 \\
\pm 0.29^{\mathrm{c}}\end{array}$ & $\begin{array}{c}54.51 \\
\pm 0.29^{\mathrm{c}}\end{array}$ & $\begin{array}{l}42.24 \\
\pm 0.72^{\mathrm{b}}\end{array}$ \\
\hline 2 & $\begin{array}{l}\mathrm{M} \\
\mathrm{D}\end{array}$ & 62 & $\begin{array}{l}332.77 \\
\pm 1.91^{\mathrm{c}}\end{array}$ & $\begin{array}{l}56.40 \\
\pm 0.32^{\mathrm{c}}\end{array}$ & $\begin{array}{c}54.94 \\
\pm 0.32^{\mathrm{c}}\end{array}$ & $\begin{array}{l}44.64 \\
\pm 0.80^{\mathrm{bc}}\end{array}$ \\
\hline 3 & $\begin{array}{l}\mathrm{M} \\
\mathrm{D}\end{array}$ & 25 & $\begin{array}{l}327.85 \\
\pm 3.00^{\mathrm{bc}}\end{array}$ & $\begin{array}{l}55.62 \\
\pm 0.51^{\mathrm{bc}}\end{array}$ & $\begin{array}{c}54.22 \\
\pm 0.51^{\mathrm{bc}}\end{array}$ & $\begin{array}{l}43.59 \\
\pm 1.25^{\mathrm{bc}}\end{array}$ \\
\hline 4 & $\begin{array}{l}\mathrm{M} \\
\mathrm{D}\end{array}$ & 4 & $\begin{array}{r}307.38 \\
\pm 7.52^{\mathrm{a}} \\
\end{array}$ & $\begin{array}{l}52.79 \\
\pm 1.26^{\mathrm{a}} \\
\end{array}$ & $\begin{array}{c}51.33 \\
\pm 1.27^{\mathrm{a}}\end{array}$ & $\begin{array}{l}38.80 \\
\pm 3.14^{\mathrm{ab}}\end{array}$ \\
\hline
\end{tabular}

${ }^{a b c}$ : Different letters in the same column differed $(\mathrm{P}<0.05)$. $\mathrm{HCW}=$ Hot carcass weight, $\mathrm{PHCW}=$ Percentage of hot carcass weight, $\mathrm{PCCW}=$ Percentage of chilled carcass weight, $\mathrm{SKW}=$ Skin weight.

Skin wt. of MB with zero pair of permanent incisors was the highest $(52.22 \pm 1.16 \mathrm{~kg})$, but did not differ from FB in the same age group $(50.08 \pm 4.44 \mathrm{~kg})$. The lowest skin wt. was found in FD with the $4^{\text {th }}, 3^{\text {rd }}$, and $2^{\text {nd }}$ pairs of permanent incisors $(37.01 \pm 0.39,38.26 \pm 0.64$, and $38.46 \pm 0.92 \mathrm{~kg}$, respectively) and in MD with the 4th pairs of permanent incisors $(38.80 \pm 3.14 \mathrm{~kg})$

Figure 1 shows percentages of animals at each age category within each cattle group obtained marbling 
scores 1 to 5. Marbling score is an important trait for adding value to the chilled carcass weight. The most mature $\left(4^{\text {th }}\right.$ pair) $\mathrm{FB}, \mathrm{MB}$, and FD had the highest marbling score of $5(30.43,52.17$, and $17.39 \%$, respectively). Marbling score 5 was not observed in any age categories of MD. MB with the $2^{\text {nd }}$ pairs of permanent incisors were graded marbling score 4 (39.02\%).

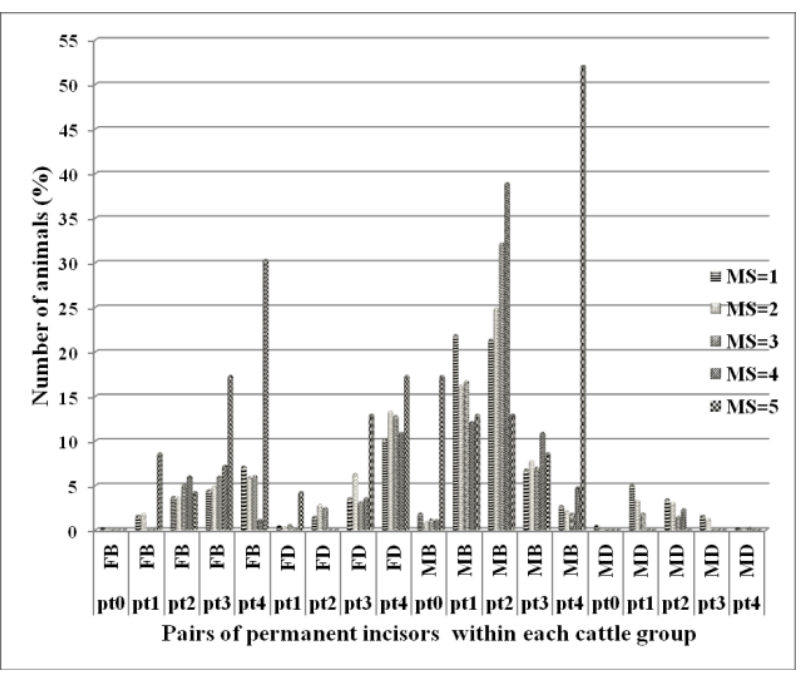

Fig. 1. Percentages of cattle with $0,1^{\text {st }}, 2^{\text {nd }}, 3^{\text {rd }}$, and $4^{\text {th }}$ pairs of permanent incisors (pt0 to pt4) within each group of cattle, which were graded 1 to 5 marbling score (MS).

In conclusion, hot carcass wt., percentage of hot or chilled carcass wt., and skin wt. of FB and MB from all ages were greater than those of the dairy cattle. MD cattle with 0-3 pairs of permanent incisors had greater hot carcass wt., percentage of hot or chilled carcass wt., and skin wt. than FD cattle, except for marbling score. Therefore, MD cattle with less than 4 pairs of permanent incisors can be raised as finished cattle. However, profit optimization from finishing FD and MD cattle should be further studied.

We would like to thank Mr.Sitthiporn Boorananath, Beef Cluster Cooperative Limited (Maxbeef), Kamphaengsaen, Nakhon Pathom Province, for data supporting.

\section{References}

1. Number of Livestock in Thailand in the Year 2015. Department of Livestock Development, 193 pp. (2015)

2. Report Operating Result: Strategy for Promotion and Development of Thai Beef Cattle Industrial System. Sub-committee on Agricultural Productivity Examination, 139 pp. (2017)

3. P.E. Strydom. S. Afr. j. anim. sci. 41, 3 (2011)

4. T. E. Lawrence, J. D. Whatley, T. H. Montgomery, and L. J. Perino. J. Anim. Sci. 79 (2001)

5. K. Tuntivisoottikul and K. Worawong. Agricultural Sci. J. Vol. 48, 2 (2017)
6. S. Sawanon. Kasetsart Livestock Magazine. 39, 153 (2012)

7. P. Tavitchasri, T. Kanloung, T. Phonmum, N. Prachachet, and N. Ngamyeesoon. $63^{\text {rd }}$ International Congress of Meat Science and Technology, Cork, Ireland (2017)

8. Crawford, G. Minnesota Farm Guide, University of Minnesota Beef Team. USA. (2010)

9. Fiems, L.O., Campeneere, S. De, Caelenbergh, W. Van, De Boever, J.L. and Vanacker J.M. Meat Sci. 63 (2003)

10. Minchin, W., Buckley, F., Kenny, D.A., Monahan, F.J., Shalloo, L., and O’Donovan, M. Meat Sci. 81, 1 (2009)

11. Schnell, T. D. K. E. Belk, J. D. Tatum, R. K. Miller, and G. C. Smith. J. Anim. Sci. 75 (1997)

12. Wardynski, F. 2012. Available source: http://msue.anr.msu.edu/experts/frank wardynski

13. TACFS 6001: Beef. 2004. Available source: http://www.acfs.go.th/eng/commodity_standard. php

14. SAS. 1999. SAS/STAT User's Guide: Statistic, SAS Institute Inc. North Carolina.

15. D. R. Buege. Meat Facts and Analysis 88, 1 Univ. WI-Extension (1988)

16. A. Y. M. Nour, M. L. Thonney, J. R. Stouffer, and W. R. C. White. J. Anim. Sci. 57 (1983)

17. St. C. S Taylor, and J. I. Murray. Anim. Prod. 53 (1991)

18. A. Y. M. Nour, M. L. Thonney, J. R. Stouffer, and W. R. C. White. J. Anim. Sci. 57 (1983)

19. W. Sukjai, Y. Opatpatanakit and T. Supphakitchanon. KHON KAEN AGR. J. 40 SUPPLMENT (2012)

20. S. Noidad, R. Lertpatarakomol,and M. Rakthong. Proceeding of the $5^{\text {th }}$ Meat Science and Technology, KMITL. (2014a).

21. S. Noidad, R. Lertpatarakomol,and $M$. Rakthong. Proceeding of the $5^{\text {th }}$ Meat Science and Technology, KMITL. (2014b). 